\title{
Studi Tentang Siswa Yang Memiliki Sikap Narsisme Dan Penagananya Melalui Latihan Bertanggun Jawab Dalam Konseling Gestal
}

\author{
Rudi \\ Jurusan pendidikan bimbingan dan konseling, STKIP Andi Matappa. \\ Corespondensi email: rudi@yahoo.com
}

\begin{abstract}
Abstrak: Penelitian ini bertujuan untuk mengetahui, faktor penyebab narsisme di SMP Negeri 1Pangkajene, penerapan latihan bertanggung jawab untuk mengatasi masalah narsisme siswa SMP Negeri 1 Pangkajene, Untuk mengetahui bagaimana penerapan latihan bertanggung jawab dalam mengatasi masalah narsisme siswa SMP Negeri 1 pangkajene. Penelitian ini merupakan penelitian Kualitatif dengan jenis penelitian Studi Kasus. Teknik pengumpulan data penelitian ini adalah Observasi (Pengamatan), Interview (Wawancara), Dokumentasi. Subjek dalam penelitian studi kasus ini ditentukan dengan purposive adalah siswa yang mengalami masalah terisolir di sebabkan sifat yang narsis yaitu SSP. Hasil penelitian menunjukkan bahwa (1) Bentuk narsis yang dialami SSP dapat dilihat dengan tidak dapat menerima saran dari orang lain bila tidak menguntungkan dirinya (egoism), sering mengucapkan kalimat yang dapat menyinggung perasaan orang lain (sadism), tidak mau peduli terhadap orang lain (cuek), sering memerintah orang lain (rasa ingin menguasai teman), punya perkumpulan sendiri yang sering berkumpul dengan orang yang sering memberikan pujian.
\end{abstract}

Kata Kunci: Memiliki Sikap, Narsisme, Penanganannya, Latihan Bertanggun Jawab

\begin{abstract}
This study aims to determine, factors cause narcissism in SMP Negeri 1Pangkajene, And the implementation of the exercise responsible for solving the problem of student narcissism SMP Negeri 1 Pangkajene, To find out how the implementation of the training is responsible for solving the problem of student narcissism SMP Negeri 1 Pangkajene. This research is qualitative research with Case Study study type. Technique of collecting data of this research is Observation (Observation), Interview (Interview), Documentation. Subjects in this case study study were determined by purposive are students who experience isolated problems caused by the narcissistic nature of the CNS. The results show that (1) Narcissistic forms experienced by the CNS can be seen by not being able to accept suggestions from others when they are unfavorable (egoism), often uttering offensive sentences (sadism), not caring about others Ignorant), often ruling others (curiosity), have their own assemblies that often gather with people who often give praise.
\end{abstract}

Keywords: Attitude, Narcissism, Handling, Behavioral Training

\section{PENDAHULUAN}

Pendidikan merupakan sarana mutlak yang dipergunakan untuk mewujudkan masyarakat madani yang mampu menguasai, mengembangkan, mengendalikan dan memanfaatkan ilmu pengetahuan dan teknologi. Output pendidikan belum mampu berjalan seimbang dengan tuntutan zaman, hal ini disebabkan minimnya penguasaan terhadap disiplin ilmu yang diperoleh melalui proses pendidikan. Keadaan ini menjadi tantangan bagi para pendidik untuk mempersiapkan peserta didiknya dalam menata masa depan. 
Untuk dapat mewujudkan hal tersebut, sebagai seorang pendidik maka harus mengetahui konsep kemanusiaan yang seutuhnya, sebagaimana tertuang dalam tujuan pendidikan nasional yaitu mencerdaskan kehidupan bangsa dan mengembangkan manusia Indonesia seutuhnya, yaitu manusia yang beriman dan bertaqwa terhadap Tuhan Yang Maha Esa dan berbudi pekerti luhur, memiliki pengetahuan dan keterampilan, kesehatan jasmani dan rohani, kepribadian yang mantap dan mandiri serta rasa tanggung jawab kemasyarakatan dan kebangsaan.

Hurlock (Hasbahuddin, 2015) mengemukakan bahwa sekolah merupakan faktor penentu bagi perkembangan kepribadian anak (siswa) baik dalam berfikir, bersikap maupun berperilaku. Sekolah sebagai tempat kedua dan substitusi keluarga dan guru substitusi orang tua.

Achmad Juntika Nurihsan menyatakan (2005: 1) bahwa: Pendidikan yang bermutu dalam penyelenggaraannya tidak cukup hanya dilakukan melalui transformasi ilmu pengetahuan dan teknologi, tetapi harus didukung oleh peningkatan profesionalisasi dan sistem manajemen tenaga kependidikan serta pengembangan kemampuan peserta didik untuk menolong diri sendiri dalam memilih dan mengambil keputusan demi pencapaian citacitanya

Agar dapat mewujudkan hal tersebut, maka setiap permasalahan yang dialami siswa perlu penanganan sedini mungkin supaya individu dapat memahami diri dan lingkungannya demi mencapai cita-cita untuk kebahagiaan hidup.

Individu yang sering merasa diri sangat penting, merasa diri lain dari yang lain, dan senang dipuji secara belebihan adalah salah satu dari peneyebab munculnya perilaku narsis yang menyebabkan mereka untuk merasakan dan berperilaku dalam cara-cara mengasingkan diri dari ruang sosial, membatasi kemampuan mereka untuk berhubungan dengan lingkungan lain di luar lingkungan mereka, seperti sekolah. Sebagaimana yang dialami oleh salah satu siswa SMP Negeri 1 Pangkajene yang susah bergaul, susah mendapat teman khususnya dalam belajar kelompok, karena selalu diacuhkan temannya.

Dari konsep pemahaman diri, maka setiap perilaku cinta diri yang berlebihan, sering bebicara akan kehebatan diri secara berlebihan, tidak mau mendengarkan apa pendapat orang lain dan selalu ingin mendapat pujian dari orang lain, tidak mau peduli terhadap orang lain, hal seperti ini perlu mawas diri karena perilaku seperti itu adalah suatu yang bermasalah.

Berdasarkan keterangan di atas, maka siswa seperti ini dikategorikan mengalami suatu masalah sehingga dianggap perlu mendapatkan bantuan dari seorang ahli untuk dapat menemukan letak permasalahan yang dialami serta dapat mengambil suatu keputusan untuk keluar dari permasalahannya. Apabila tidak ditangani secepatnya dengan teknik atau pendekatan konseling yang tepat maka akan berdampak kepada prestasi belajarnya. Melaksanakan konseling, perlu pemahaman mendalam tentang teori-teori yang berkaitan dengan konseling, ini sangat penting bagi konselor agar dapat memberikan bantuan kepada konseli dengan maksimal. Selain itu teori memberikan landasan bagi konselor untuk membedakan tingkah laku yang normal-rasional, dengan yang abnormal-irasonal, serta membantu memahami penyebab tingkah laku dan cara untuk membantu menyelesaikannya. Sesuai dengan permasalahan yang dialami siswa di atas, yang berlandaskan penjelasan teori tersebut dapat menggunakan pendekatan gestalt dengan teknik latihan bertanggung jawab

Menurut Gantina Komalasari, dkk (2011: 290). Menyatakan bahwa:

pendekatan gestalt, area yang paling penting yang harus diperhatikan dalam konseli adalah pemikiran dan perasaan yang individu alami pada saat sekarang. Perilaku normal dan sehat terjadi bila individu bertindak dan beraksi sebagai organisme yang total, yaitu memiliki kesadaran pada pemikiran, perasaan pada masa sekarang. Banyak orang memisahkan kehidupan yang lebih berkonsentrasi serta memfokuskan perhatiannya pada poin-poin dan kejadiankejadian tertentu dalam kehidupannya...

Dari penjelasan di atas, dapat dipahami bahwa konseling gestalt fokus pada pikiran, perasaan yang individu alami pada saat sekarang dan melihat secara keseluruhan dari masalah yang dialami sehingga konselor mampu mendorong konseli untuk dapat melihat kenyataan yang ada pada dirinya serta mau mencoba menghadapinya secara penuh.

Fenomena tersebut di atas, terungkap setelah mengadakan observasi awal sehingga diperoleh keterangan dari teman-temannya dan keterangan Guru bimbingan dan konseling SMP Negeri 1 Pangkajene bahwa dalam lingkungan sekolahnya ada salah satu dari siswanya yang memiliki 
masalah sebagaimana yang disebutkan di atas yang merupakan suatu gambaran sifat narsisme.

Berdasarkan kajian maka peneliti memandang penting untuk meneliti perilaku narsisme siswa di sekolah. Dari fenomena itu diangkatlah judul ini untuk dikaji dan diteliti sejauh mana penerapan latihan bertanggung jawab (teknik konseling gestalt) terhadap masalah narsisme siswa di SMP Negeri 1 Pangkajene sebagai studi kasus pada 1 orang siswa.

Secara sains tidak ditemukan sebab-sebab yang sifatnya mengungkapkan narsis. Tetapi banyak riset yang mengungkapkan bahwa ada faktor tertentu yang menandakan bahwa seseorang itu memiliki gangguan kepribadian narsistik sebagaimana keterangan yang disebutkan oleh Nurawalia (2009) diakses tanggal, 18, januari, 2014 antara lain; (1).Merasa dirinya sangat penting dan ingin dikenal oleh orang lain, (2).Merasa diri unik dan istimewa, (3). Suka dipuji dan jika perlu memuji diri sendiri, (4). Kecanduan difoto atau di shooting, (5). Suka berlama lama di depan cermin, (6). Kebanggan berlebih.

Sedangkan menurut Ikhlas putra Amin (2010) yang diakses, 7, januari, 2015 mengemukakan bahwa penyebab terjadinya Narsisme yaitu, adanya gangguan kepribadian narsis yang merupakan gangguan kronis dan sulit untuk mendapatkan perawatan, oleh karena suka mengambil keuntungan dari orang lain demi kepentingan diri sendiri, sering berprilaku sombong (congkak), erasa diri paling gagah/ cantik. Prilaku seperti ini mengakibatkan individu kuarang disenangi oleh temannya, kecuali orang yang suka memberikan pujian demi menjaga keutuhan kelompoknya.

Dari penjelasan di atas, dapat diketahui beberapa faktor penyebab narsisme yaitu, merasa sangat penting, merasa diri unik, suka dipuji, kecanduan difoto, suka mengambil keuntungan dari orang lain demi kepentingan diri sendiri.

Konseling gestalt terdiri dari beberapa teknik sebagaimana dikemukakan oleh Gantina Komalasari, Eka Wahyuni, Krasih, (2011: 318323) di ataranya:

Teknik kursih kosong (Empaty Chair), Topdog versus underdog, Membuat serial (Making The Rounds), Latihan melebih-lebihkan (The Exaggertion Experiment),

Saya bertanggung jawab atas...." ("I" Take Responsibility For....")
Teknik ini bertujuan membantu konseli untuk menyadari dan mempesonalisasi perasaan dan tingkah lakunya serta mengambil tanggung jawab atas perasaan dan tingkah lakunya. Konseli diminta untuk mengisi bagian kosong sebagai cara mengevaluasi tanggung jawab personal dan bagaimana konseli mengatur hidupnya.

Berdasarkan penjelasan di atas, dapat dipahami bahwa dalam konseling gestalt terdiri dari beberapa teknik konseling yang dapat dikembangkan dan diberikan untuk membantu konseli dalam mengatasi masalahnya. Konseling yang dimaksud adalah teknik "Saya bertanggung jawab atas....". Pada penelitian ini menggunakan teknik tersebut sebab fokus utama teknik ini, bertujuan membantu konseli untuk menyadari dan mempersonalisasi perasaan dan tingkah lakunya serta mengambil tanggung jawab atas perasaan dan tingkah lakunya.

Filsafat Gestalt menekankan pentingnya tanggung jawab diri. Hal itu dinyatakan dengan baik oleh Eleanor O'Leary, psikolog dan psikoterapis dalam Stephen Palmer (Ed) (2011: 151) dalam bukunya berjudul Konseling dan Psikoterapi:

Bertanggung jawab pada diri sendiri adalah inti terapi Gestalt. Klien dibantu untuk berpindah dari posisi ketergantungan pada orang lain, termasuk pada terapis, ke keadaan yang bisa menundukkan diri sendiri. Klien didorong untuk melakukan banyak hal secara mandiri. Awalnya klien melihat perasaan, emosi dan masalahnya sebagai sesuatu diluar dari dirinya: digunakan frasa-frasa seperti 'ia membuatku merasa sangat bodoh'. Klien tidak bertanggung jawab atas dirinya, didalam pandangannya tak ada yang bisa dia lakukan terhadap situasi itu kecuali menerima begitu saja. Klien tidak melihat dirinya telah punya masukan atau kendali atas kehidupannya. Klien dibantu menyadari bahwa dia bertanggung jawab atas hal yang terjadi pada dirinya. Dialah yang harus memutuskan apakah harus mengubah situasi kehidupannya atau membiarkan tidak berubah.

Sementara tanggung jawab menurut Kamus Besar Bahasa Indonesia yaitu "keadaan wajib menanggung segala sesuatunya" (Departemen Pendidikan Dan Kebudayaan 1992: 899). "Latihan tanggung jawab merupakan teknik yang dimaksudkan membantu konseli agar mengakui dan menerima perasaan-perasaanya daripada memproyeksikan perasaannya itu kepada orang lain", (Putra Jaya 2012: 108). 
Berdasarkan penjelasan di atas, dapat disimpulkan bahwa latihan saya bertanggung jawab adalah bagaimana individu melepaskan ketergantungannya kepada orang lain sehingga mampu menerima keadaan dirinya sesuai dengan pilihannya untuk dapat merubah kehidupannya atau membiarkan tidak berubah.

Menurut Gantina Komalasari, dkk, (2011: 321) mengatakan:

Pelakasanaan teknik latihan saya bertanggung jawab dalam konseling gestalt pempunyai tujuan yaitu membantu konseli untuk menyadari dan mempersonalisasi perasaan dan tingkah lakunya. Konseli diminta mengisi bagian kosong sebagai cara mengevaluasi tanggung jawab personal dan bagaimana konseli mengatur hidupnya.

Contoh: konseli diminta untuk berkata: "saya merasa kesepian dan saya bertanggung jawab atas perasaan saya". Latihan ini dapat membuka mata konseli yang biasanya cenderung melihat orang lain sebagai sumber perasaan baik dan buruk Thompson,

Sementara Perls mengemukakan dalam Richard Nelson-Jones, (2011: 215-217) teori dan praktik konseling dan terapi

Perls tertarik dengan semantik dan ia menyadari tentang bagaimana klien dapat menginterfensi self-support melalui penggunaan bahasa yang buruk (Livitsky \& Perls, 1970; Perls 1970a). Menggunakan kata kerja yang mengakui pilihan dan agency personal adalah suatu contoh penggunaan bahasa tanggung jawab: misalnya, mengubah frasa "I can't do that" (aku tidak bisa melakukan itu) menjadi "I wan't do that" (aku tidak mau melakukan itu). Disamping itu, klien dapat diperingatkan untuk kata ganti orang "I" (orang pertama tunggal) dan bukan "It" (orang ketiga tunggal) atau "they" ( orang ketiga jamak) dan mengirimkan pesan secara langsung kepada terapisnya dan kepada orang yang lain. Disamping itu, jika klien mengajukan pertanyaan-pertanyaan yang memanipulasi lingkungan untuk mendapatkan dukungan, terapis dapat mendorong klien untuk mengubah pertanyaan pasif menjadi pertanyaan aktif dan self-supporting.

Putra Jaya mengemukakan dalam teori dan praktik konseling, (2012: 108) latihan saya bertanggung jawab yaitu:

Merupakan teknik yang dimaksudkan untuk membantu konseli agar mengakui dan menerima perasaan-perasaannya dari pada memproyeksikan perasaannya itu kepada orang lain. Dalam teknik ini konselor meminta konseli untuk membuat suatu pernyataan dan kemudian konseli menambahkan dalam pernyataan itu dengan kalimat: “.... dan saya bertanggung jawab atas hal itu"

Misalnya: "saya merasa jenuh, dan saya bertanggung jawab atas kejenuhan itu"

"saya tidak tahu apa yang harus saya katakan sekarang, dan saya bertanggung jawab atas ketidaktahuan itu"

"saya malas dan saya bertanggung jawab atas kemalasan itu"

Meskipun tampaknya mekanis, tetapi menurut Gestalt akan membantu meningkatkan kesadaran konseli akan perasaan-perasaan yang mungkin selama ini diingkarinya.

Berdasarkan penjelasan di atas, maka diketahui bahwa dalam teknik latihan bertanggung jawab dalam konseling gestalt mempunyai tujuan yaitu membantu konseli untuk menyadari dan mempersonalisasi perasaan dan tingkah lakunya serta klien diminta mengisi bagian yang kosong sebagai cara mengevaluasi tanggung jawab personal. Dalam teknik ini konselor meminta konseli untuk membuat suatu pernyataan dan kemudian konseli menambahkan dalam pernyataan itu dengan kalimat: “.... dan saya bertanggung jawab atas hal itu" sebagaimana contoh di atas.

Fokus utama konseling gestalt adalah terletak pada bagaimana keadaan klien sekarang serta hambatan-hambatan apa yang muncul dalam kesadarannya. Oleh karena itu tugas konselor adalah mendorong klien untuk dapat melihat kenyataan yang ada pada dirinya serta mau mencoba menghadapinya. Dalam hal ini perlu diarahkan agar klien mau belajar menggunakan perasaannya secara penuh. Untuk itu klien bisa diajak untuk memilih dua alternatif, ia akan menolak kenyataan yang ada pada dirinya atau membuka diri untuk melihat apa yang sebenarnya terjadi pada dirinya sekarang. Sebagaimana dijelaskan oleh Fitrakal (2012) diakses, 22, November, 2014) sebagai berikut: (1). Konselor hendaknya menghindarkan diri dari pikiran-pikiran yang abstrak, keinginankeinginannya untuk melakukan diagnosis, interpretasi maupun memberi nasihat. (2).Konselor sejak awal konseling sudah mengarahkan tujuan agar klien menjadi matang dan mampu menyingkirkan hambatan-hambatn yang menyebabkan klien tidak dapat berdiri sendiri. Dalam hal ini, fungsi konselor adalah 
membantu klien untuk melakukan transisi dari ketergantungannya terhadap faktor luar menjadi percaya akan kekuatannya sendiri. Usaha ini dilakukan dengan menemukan dan membuka ketersesatan atau kebuntuan klien. (3).Pada saat klien mengalami gejala kesesatan dan klien menyatakan kekalahannya terhadap lingkungan dengan cara mengungkapkan kelemahannya, dirinya tidak berdaya, bodoh, atau gila, maka tugas konselor adalah membuat perasaan klien untuk bangkit dan mau menghadapi ketersesatannya sehingga potensinya dapat berkembang lebih optimal.

Berdasarkan penjelasan di atas, dapat dipahami tentang deskripsi proses konseling gestalt dimana seorang konselor hendak menghindari pikiran yang abstrak atau keinginan untuk melakukan interpensi, memberikan nasehat. Konselor sejak awal sudah mengarahkan tujuan agar konseli menjadi mantap, mampu menyingkirkan semua halangan yang dapat membuat klien tidak sanggup berdiri sendiri dalam hal ini fungsi konselor membantu konseli untuk dapat beralih dari ketergantungan terhadap faktor luar menjadi percaya akan kemampuan diri sendiri, saat klien mengalami gejala kesesatan dan menyatakan kekalahannya terhadap lingkungan dengan cara mengatakan kelemahan dirinya sendiri maka tugas konselor membuat perasaan klien bangkit dan mau menghadapi kesesetannya itu demi mengembangkan potensi diri konseli secara optimal.

Berdasarkan dengan permasalahan yang dilami oleh peserta didik tesebut maka dianggap bahwa pendekatan yang diberikan sudah relevan yaitu konseling gestalt.

sebagaimana asumsi dasar terapi gestalt terhadap manusia yang magatakan bahwa idividu-idividu memiliki kapasitas untuk mengatur diri sendiri ketika mereka menyadari apa yang terjadi. Terapi menyediakan situasi dan kesempatan utuk menunjang dan merotasi kesadaran. Jika ahli terapi memahami pengalaman konseli saat sekarang dan mempercayai proses, konseli akan bergerak kearah kesadaran, kontak, dan integrasi yang meningkat (Putra Jaya 2012: 97)

Pendekatan konseling ini berpandangan bahwa manusia dalam kehidupannya selalu aktif sebagai suatu keseluruhan. Setiap individu bukan semata-semata merupakan penjumlahan dari bagian-bagian orang-orang seperti hati, jantung, otak dan sebagainya melainkan merupakan suatu koordinasi semua bagian tersebut.

Berdasarkan dengan penjelasan di atas, yang mengatakan bahwa di SMP Negeri 1 pangakajene terdapat peserta didik yang berprilaku cinta diri yang berlebihan, mengagungkan diri yang berlebihan, tidak mau mendengarkan apa pendapat orang lain merupakan suatu prilaku yang mencerminkan sifat narsisme yang menyebabkan susahnya bergaul dan dihindari orang lain.

Dari prilaku seperti ini peserta didik tersebut perlu mendapatkan penanganan melalui bimbingan dan konseling dengan metode tertentu dalam hal ini pendeketan gestalt dengan teknik latihan tanggung jawab. Melihat fenomena di atas penulis menganggap bahwa individu tersebut kurang bertanggung jawab dengan dirinya. Dengan teknik latihan bertanggung jawab konseli diharapkan dapat menyadari segala potensi dirinya sehingga dapat berubah dengan penuh rasa tanggung jawab terhadap dirinya tanpa adanya intervensi dari luar.

\section{METODE}

Penelitian ini dilaksanakan di SMP Negeri 1 Pangkajene. Dengan pertimbangan bahwa sekolah tersebut merupakan salah satu sekolah ungulan. Umumnya siswa di SMP Negeri 1 Pangkajene memiliki prestasi gemilang baik tingkat Kabupaten maupun tingkat Nasional, namun tidak sedikit siswa yang mengalami berbagai permasalahan baik ringan atau pun berat. Permasalahan yang sering terjadi pada siswa rata-rata karena masalah pribadi, masalah sosial dan masalah belajar, untuk itu meneliti bermaksud mengkaji lebih jauh tentang prilaku narsisme siswa yang berlebihan terhadap diri sendiri dengan pendekatan konseling gestalt dan teknik latihan bertanggung jawab sebagai satu upaya yang dilakukan oleh konselor dalam mengatasi berbagai permasalahan siswa di SMP Negeri 1 Pangkajene.

Pendekatan yang digunakan dalam penelitian ini adalah pendekatan kualitatif dengan jenis studi kasus. Penelitian ini bertujuan untuk mendeskripsikan fenomena-fenomena sosial dari sudut atau perspektif partisipan dalam arti penelitian ini difokuskan pada satu fenomena saja yang dipilih dan ingin dipahami secara mendalam, dengan mengabaikan fenomena lainnya. 
Deskripsi fokus akan membatasi pengertian penulis dan pembaca tentang fokus masalah yang dimaksud dalam penelitian ini: (1) Bentukbentuk narsisme dapat dilihat dari sifat individu seperti; egoisme, sadisme, cuek, rasa ingin berkuasa, selalu berbicara kehebatan dirinya sendiri, selalu berkumpul dengan orang yang sering memberikan pujian. (2) Faktor-faktor penyebab narsisme adalah prilaku memperhatikan diri sendiri secara berlebihan dengan indikator, merasa dirinya sangat penting, merasa diri unik, suka dipuji, kecanduan difoto. (3) Bentuk penerapan latihan bertanggung jawab yaitu memberikan konseling individu dengan pendekatan gestalt yaitu memberikan kalimat pernyataan yang tidak lengkap kemudian konseli melengkapi kalimat pernyataan tersebut dengan menambahkan "Saya ber tanggung jawab"

Untuk melaksanakan penelitian dan memperoleh data yang dibutuhkan, maka pengumpulan data perlu dilakukan. Dalam penelitian ini penulis menggunakan beberapa metode pengumpulan data. Adapun pengumpulan data yang penulis gunakan dalam penelitian ini adalah sebagai berikut:

Observasi adalah metode pengumpulan data melalui pengamatan langsung atau peninjauan secara cermat dan langsung di lapangan atau lokasi penelitian. Dalam hal ini, peneliti dengan berpedoman kepada desain penelitiannya perlu mengunjungi lokasi penelitian untuk mengamati langsung berbagai hal atau kondisi yang ada di lapangan.

Berdasarkan keterlibatan pengamatan dalam kegiatan-kegiatan orang yang diamati, maka peneliti menggunakan metode observasi partisipasi (participant observation)

Syarat sebuah observasi partisipan jika kita yang mengadakan pengamatan (disebut pengamat atau observer) turut ikut serta dalam kehidupan orang, atau orang-orang yang kita amati disebut observer.

Metode interview atau wawancara adalah cara pengumpulan data yang dilakukan melalui percakapan antara peneliti dengan subyek yang diteliti atau responden atau sumber data. DengAn proses tanya jawab yang berlangsung secara lisß? dengan Guru BK dan Siswa yang bersangkutą: Bertatap muka serta mendengarkan secara langsung informasi atau keterangan-keterangan tentang masalah yang terkait terhadap satu orang siswa di SMP Negeri 1 Pangkajene.

Dokumentasi adalah penelitian dengan menyelidiki benda-benda tertulis seperti buku, dokumen, peraturan-peraturan, catatan harian atau kegiatan dan sebagainya.

Metode dokumentasi dalam penelitian ini adalah metode pengumpulan data yang digunakan sebagai suatu pendukung dari wawancara untuk mengetahui dan mencatat data tentang latar belakang objek penelitian dan untuk memperoleh data mengenai keberhasilan pelaksanaan kegiatan studi kasus terhadap penyelesaian masalah di SMP Negeri 1 Pangkajene

Teknik analisis data yang digunakan darai hasil penelitian, penulis menganalisa dengan menitikberatkan pada sisi kualitatifnya. Sehingga nampak bahwa teknik latihan bertanggung jawab layanan studikasus dalam bidang bimbingan dan konseling itu efektif dilaksanakan oleh guru pembimbing terhadap penyelesaian masalah siswa di SMP Negeri 1 Pangkajene dalam penganalisaan data ini digunakan beberapa metode.

Reduksi data merupakan suatu proses pemilihan, pengabstrakan, dan transformasi data "kasar" yang muncul dari catatan-catatan tertulis di lapangan. Reduksi data ini berlangsung secara terus menerus selama proyek yang berorientasi kualitatif berlangsung.

Display data merupakan sekumpulan informasi tersusun yang memberi kemungkinan adanya penarikan kesimpulan dan pengambilan tindakan. Dengan melihat penyajian-penyajian, kita akan dapat memahami apa yang sedang terjadi dan apa yang harus dilakukan berdasarkan atas pemahaman yang kita dapat dari penyajianpenyajian tersebut.

1. Penarikan Kesimpulan

Kesimpulan-kesimpulan dilakukan verifikasi selama penelitian berlangsung secara sederhana, makna-makna yang muncul dari data harus diuji kebenaran, kekuatan, dan kecocokannya, yakni yang merupakan validitasnya, jika tidak demikian, yang kita miliki adalah cita-cita yang menarik mengenai sesuatu yang terjadi dan yang tidak jelas kebenaran dan kegunaannya.

\section{SIMPULAN DAN SARAN}

Berdasarkan dari beberapa hasil penelitian dan pembahasan, maka kesimpulan yang dapat diambil adalah sebagai berikut:

1. Bentuk narsisme siswa dapat dikenali dengan beberapa ciri tertentu seperti, tidak dapat menerima saran dari orang lain bila tidak 
menguntungkan dirinya (egoism), sering mengucapkan kalimat yang dapat menyinggung perasaan orang lain (sadism), tidak mau peduli terhadap orang lain (cuek), sering memerintah orang lain (rasa ingin menguasai teman), punya perkumpulan sendiri yang sering berkumpul dengan orang yang sering memberikan pujian.

2. Faktor-faktor penyebab narsisme adalah prilaku memperhatikan diri sendiri secara berlebihan dengan indikator, merasa dirinya sangat penting, merasa diri unik, suka dipuji, kecanduan difoto.

3. Bentuk penerapan latihan bertanggung jawab yaitu memberikan konseling individu dengan pendekatan gestalt yaitu memberikan kalimat pernyataan yang tidak lengkap kemudian konseli melengkapi kalimat pernyataan tersebut dengan menambahkan "Saya ber tanggung jawab"

Sehubungan dengan hal di atas, maka peneliti perlu menyampaikan saran-saran sebagai berikut:

1. Guru bimbingan dan konseling selaku konselor sekolah peneliti mengaharapkan agar senantiasa mengontol perkembangan SSP setelah di berikan layanan konnseling individual dengan teknik latihan bertanggung jawab.

2. Guru bimbingan dan konseling diharapakan berkolaborasi dengan guru bidang studi dan wali kelas serta orang tua siswa dalam pengontol/ mendapingi siswa baik yang mengalami masalah maupun yang tidak mengalaimi masalah.

3. Diharapkan kepada kepala sekolah supaya jam tatap muka diberikan kepada konselor walau hanya satu kali pertemuan dalam satu minggu supaya guru bimbingan dan konseling dapat melaksanakan tugas dan tanggung jawabnya sebagai bagian dari pendidik.

\section{DAFTAR RUJUKAN}

Anthony Dio Martin, 2010, Up Your Life, Raih Asa Sukses, (Penebar Swadaya Group), Jakarta

Andar Ismail, 2008, Selamat Berbakti 33 Renungan Tentang Ibadah, PT. BPK Gunung Mulia, Jakarta

Achmat Juntuka Nurihsan, 2005, Strategi Layanan Bimbingan dan Konseling, PT. Refika Aditama, Bandung

Andi Prastowo, 2011, Metode Penelitian Kualitatif dalam Perspektif Rancangan Penelitian, Ar-Ruzz media, Yogyakarta
Fenti hikmawati, 2012, Bimbingan dan Konseling Edisi Revisi, PT Raja Grafindo Persada, Jakarata

Fitrikal, 2012, Konseling-Gestalt, (Online) http://fitrika1127.blogspot.com. (diakses, 22, November, 2014)

Gantina Komalasri, Eka Wahyuni, dan Karsih, (Eds), 2011, Teori dan Teknik Konseling, PT Indeks, Jakarta

Hasbahuddin. 2015. Penerapan Pendidikan Karakter Untuk Mencegah Kecenderungan Penyalahgunaan Narkoba SMK Negeri 5 Makassar Jurnal Psikologi Pendidikan \& Konseling http://ojs.unm.ac.id/index.php/JPPK

Volume 1 Nomor 2 Desember 2015. Hal 93-104 p-ISSN: 2443-2202 e-ISSN: 2477-2518

Henry Cloud, 2007, Keberanian Memenuhi Tuntutan Kenyataan, PT. Gramedia Pustaka Utama Jakarta

Ikhlas putra Amin, 2010, Gangguan Narsisme, (Online), $\quad$ www.ikhlasputra.com. (diakses, 7, januari, 2015)

Kamusbesar Bahasa Indonesia, 1992, Departemen Pendidikan dan Kebudayaan, Balai Pustaka, Jakarta

Nurawalia, 2009, Gangguan Kepribadian Narsisme, (Online) http://nurawlia.wordpress.com. (diakses 18 November, 2014)

Putra Jaya, 2012, Teori dan Praktek Konseling, Agung Vison, Makassar

Sabel El-Ma'ruf, 2008, Latazan For Teen's Love, Meraih Kebahagiaan Cinta Sejati "Inspiratif dan Bisa Mencerahkan Cintamu" PT. Mizan Pustaka, Bandung

Sami Anotaslimboy, (ed), 2012, Kelekar Tanpa Batas Cuap-Cuap menggelitik Seorang Komic, Gagas Media, Jakarta

Sofyan S. Willis, 2011, Konseling Individual Teori dan Praktek, Alfabeta, Bandung

Stephen Palmer (Ed.), Direktur Pusat Manajemen Stres, Londondan Honorary Visting Professor Of 